\title{
TRIP13 wt Allele
}

National Cancer Institute

\section{Source}

National Cancer Institute. TRIP13 wt Allele. NCI Thesaurus. Code C118329.

Human TRIP13 wild-type allele is located in the vicinity of 5p15.33 and is approximately

$27 \mathrm{~kb}$ in length. This allele, which encodes pachytene checkpoint protein 2 homolog protein, plays a role in chromosome recombination in meiosis. 